\title{
REFLEKSI SISTEM DISTRIBUSI SYARIAH PADA LEMBAGA ZAKAT DAN WAKAF DALAM PEREKONOMIAN INDONESIA
}

\author{
Yuke Rahmawati*
}

\begin{abstract}
The Reflection of Islamic Distribution System of Zakâh and Waqf Institution for Indonesia Economy. The distribution activities always refer to subsistence and walfare. It is also closely linked to the issue of income distribution system. If there is an imbalance of income distribution, it will create an imbalance of wealth distribution. Therefore, There are two things that must be followed in order to improve the well-being. They are reducing disparities among social groups with jobs and/or provide direct assistance to poor communities so they can improve their quality of life.
\end{abstract}

Keywords: zakâh and waqf institution, islamic distributions, walfare.

\begin{abstract}
Abstrak: Refleksi Sistem Distribusi Syariah pada Lembaga Zakat dan Wakaf dalam Perekonomian Indonesia. Kegiatan distribusi selalu mengacu pada pemenuhan kebutuhan hidup dan pemerataan kesejahteraan. Hal ini juga sangat terkait erat dengan persoalan sistem distribusi pendapatan, di mana bila terjadi ketidakseimbangan distribusi pendapatan, maka akan menciptakan ketidakseimbangan distribusi kekayaan. Oleh karena itu, terdapat dua hal yang harus dipedomani dalam upaya meningkatkan kesejahteraan tersebut, yakni mengurangi kesenjangan diantara kelompok-kelompok masyarakat dengan membuka lapangan pekerjaan dan/atau memberikan bantuan langsung kepada warga masyarakat miskin agar mereka bisa meningkatkan mutu hidupnya.
\end{abstract}

Kata Kunci: lembaga zakat dan wakaf, distribusi syariah, kesejahteraan.

Naskah diterima: 25 Februari 2010, direvisi: 29 Juli 2010, disetujui: 5 Agustus 2010.

* Fakultas Syariah dan Hukum UIN Syarif Hidayatullah Jakarta. Jl. Ir. H. Juanda No. 95, Ciputat, Jakarta. E-mail: uke_rahmawati@yahoo.com 


\section{Pendahuluan}

Persoalan distribusi pada umumnya sering dikaitkan dengan persoalan sistem distribusi pendapatan (income distribution) diantara pelbagai golongan masyarakat. Dikatakan bahwa distribusi kekayaan dalam masyarakat sangat erat kaitannya dengan distribusi pendapatan. Ketidakseimbangan distribusi pendapatan akan menciptakan ketidakseimbangan distribusi kekayaan (wealth distribution). Hal ini dianggap wajar karena menyangkut masalah kesejahteraan kehidupan masyarakat, dan tidak dapat dipungkiri bahwa hasil pembangunan yang dicapai seutuhnya adalah untuk kesejahteraan masyarakat dan dapat dinikmati oleh masyarakat secara merata.

Teori ekonomi modern mengungkapkan bahwa teori distribusi merupakan suatu teori yang menetapkan harga jasa produksi. Siapa saja yang terlibat dalam suatu produksi, maka ia akan mendapatkan suatu konsekuensi dari padanya. Sebaliknya, bagi yang tidak terlibat, walau dengan alasan apapun jelas tidak akan mendapatkannya. Pengertian ini dapat memberikan pemahaman bahwa keadilan dalam distribusi diartikan sebagai memberi balas jasa pada setiap orang sesuai sumbangan yang diberikan (reward of desert).

Di sisi lain, "keniscayaan" ada manusia yang tidak bisa ikut andil di dalamnya karena barbagai alasan tertentu, menjelaskan bahwa sebagian orang bekerja dan berpenghasilan, sedang sebagian lagi tidak ${ }^{1}$ atau bahkan sebagian kecil orang kaya raya, sedang sebagian terbesarnya adalah orang miskin.

Sistem distribusi syariah mempunyai dua pedoman dasar dalam upaya meningkatkan kesejahteraan masyarakat di atas. Pertama, mengurangi kesenjangan sosial diantara kelompok-kelompok yang ada dalam masyarakat seperti membuka atau memperluas lapangan pekerjaaan dan memberikan peluang bekerja, sehingga masyarakat dapat memiliki pendapatan untuk pemenuhan kebutuhan dalam hidupnya. Kedua, secara langsung memberikan santunan dan bantuan kepada warga masyarakat miskin agar mereka secara terus menerus dapat meningkatkan mutu kehidupannya. ${ }^{2}$

Di Indonesia, sistem ekonomi yang digunakan pada dasarnya tidak kapitalis dan tidak pula sosialis. Karena sistem-sistem tersebut dianggap akan berten-

\footnotetext{
${ }^{1}$ Ketika krisis (1999), tingkat kemiskinan mencapai 27\%. Saat ini tingkat kemiskinan memang sudah menurun dibanding saat krisis yaitu 16\% (36 juta jiwa). Tetapi jika kita menggunakan tingkat kemiskinan dengan indikator mereka yang berpendapatan dibawah 2 dollar AS per hari, maka tingkat kemiskinan mencapai sekitar 53\%. Jadi tingkat kemiskinan kita masih jauh, bahkan lebih besar dibanding sebelum krisis. Khudori, Ekonomi 2004 Bergerak dalam Lumpur, lihat dalam http://www.republika.co.id/ASP/kolom detail, diunduh Selasa, 6 Januari 2004.

${ }^{2}$ Mubyarto, Islam dan Kemiskinan, (Bandung: Pustaka, 1988), h. 3.
} 
tangan dengan ideologi yang dianutnya yakni Pancasila. Namun pada kenyataannya, sistem ekonomi Indonesia terasa sangat kapitalistik, dimana lebih banyak orang terang-terangan menerima dan menjalankan sistem ekonomi tersebut karena dianggap "tidak terelakkan" dan karena sejak tahun 1991 kapitalisme telah jelas terbukti memenangkan persaingan dari sosialisme. ${ }^{3}$ Namun sejak masa reformasi, terutama sejak SI-MPR 1998, kemudian populer istilah ekonomi kerakyatan sebagai sistem ekonomi yang harus diterapkan di Indonesia.

Dalam Islam, aktivitas distribusi sudah terbentuk dalam sistem ekonominya dan merupakan prinsip utama yang ketiga dari sistem ekonomi Islam di atas tadi, yaitu memastikan dan meyakinkan bahwa peredaran kekayaaan tidak terkonsentrasi pada segelintir orang atau golongan (in a few hands) saja ${ }^{4}$. Islam juga sangat mengharamkan penimbunan akan harta, baik itu membekukannya, menahannya, maupun menjauhkannya dari peredaran.

Meski di sisi lain, Islam mengakui adanya gradasi/hirarki (tingkatan) ekonomi dalam suatu masyarakat. Namun perbedaan itu tidak untuk dijadikan sebagai perbedaan sosial atau kesenjangan, karena setiap manusia mempunyai hak untuk memenuhi kebutuhan dasarnya untuk tetap menjalani hidup. Islam menawarkan proses pendistribusian ini dengan sistem yang telah dimiliki yang pada dasarnya mengandung dua sistem distribusi utama, yakni distribusi secara komersial dan mengikuti mekanisme pasar serta sistem distribusi yang bertumpu pada aspek keadilan sosial masyarakat.

Berdirinya institusi atau lembaga-lembaga pengelola zakat dan wakaf di Indonesia, sudah menjadi bagian tak terpisahkan dalam kegiatan ekonomi masyarakat. Pemerintah bahkan menjadi bagian penting yang tak terlepas dari andil tumbuh dan berkembangnya lembaga-lembaga tersebut. Melalui lembaga, suatu sistem akan mampu dijalankan secara efektif dan efisien untuk mencapai tujuannya, mengingat lembaga memiliki strategi dan manajemen dalam melakukan segala aktivitasnya. Namun yang kemudian menjadi persoalan adalah manajemen dan strategi seperti apa yang mampu dikembangkan lembaga tersebut menjadi lembaga yang kapabel dan proporsional di bidangnya. Dikatakan bahwa dalam era revolusi informasi sekarang, keunggulan suatu lembaga tidak hanya terfokus/ditentukan oleh efisiensi dalam alokasi sumber daya atau aset berwujud (tangible resources/asset) saja, yang mudah dijabarkan dalam dimensi keuangan. Tetapi keunggulan tersebut sangat tergantung pada kemampuannya untuk memobilisasi dan mengeksploitasi sumber daya atau aset tak

\footnotetext{
${ }^{3}$ Mubyarto, Etika Bisnis Pancasila, dalam http://www.ekonomirakyat.org/edisi2/artikel.

${ }^{4}$ Q.s. al-Hasyr [59]: 7.
} 
berwujud (intangible resources/asset) yang tidak mudah dijabarkan dalam dimensi keuangan. Yang mampu menciptakan strategi berbasis pengetahuan (knowledge-based strategy), seperti menciptakan hubungan yang harmonis dengan masyarakat pelaku, mengarahkan produk dan jasa yang inovatif dan kompetitif, serta menstimulasi keterampilan dan motivasi karyawan/ pengelolanya. Dengan demikian untuk meningkatkan mutu informasi dalam proses perumusan dan implementasi strategi tersebut, diperlukan sistem informasi multidimensional yang meliputi sistem informasi keuangan dan non-keuangan. ${ }^{5}$

Terdapat beberapa hal yang berkaitan dengan sistem distribusi ekonomi ini yang dapat diterapkan dalam sistem perekonomian modern dengan pelbagai langkah strategis dalam rangka menerapkan serta mengembangkan sistem distribusi di Indonesia yang berbasis Syariah. Di antaranya sebagai berikut: Pertama, mekanisme sistem distribusi ini dalam perspektif ekonomi Islam. Kedua, hal-hal yang terkait dengan kinerja lembaga yang bergerak pada sistem distribusi berbasis syariah di Indonesia. Ketiga, faktor-faktor strategis yang harus dimiliki lembaga tersebut, melalui analisa faktor kekuatan, kelemahan, peluang, dan tantangan yang ada, untuk menempatkannya pada posisi ekonomi-strategis dalam perekonomian bangsa.

Secara teoretis, sistem distribusi pada dasarnya terbagi pada dua, yakni distribusi pendapatan (distribution of income) dan distribusi kekayaan (distribution of wealth). Distribusi pendapatan biasanya senantiasa dikaitkan dengan harga jasa produksi, yang mana hal tersebut merupakan konsekuensi dari suatu proses produksi bagi setiap usaha, baik dalam bentuk uang ataupun nilai. Kemudian hasilnya didistribusikan kepada komponen-komponen produksi yang mempunyai andil di dalamnya, di antaranya komponen ongkos (cost) untuk sewa tanah yang dipakai proyek, laba (profit), bunga (interest) sebagai imbalan dari uang modal bagi pemodal dan komponen upah (wage) bagi para pekerja/buruh.

Di Indonesia kebijakan penentuan upah diserahkan kepada pemerintah, dengan istilah UMR (Upah Minimum Regional). Di sini pemerintah harus bertindak sebagai wasit yang menengahi apabila terjadi perbedaan pendapat antara pekerja dan pemodal. Di mana di satu sisi, pekerja/buruh harus dibayar dengan sejumlah upah (wage) yang dapat mencukupi kehidupannya agar mereka berkehidupan yang laik bagi kemanusiaan. Dan di sisi lain, keadilan bagi pemodal yang dipatok pada berapa tingkat laba (rate of profit) minimun agar pemodal

${ }^{5}$ Wahyudi Prakarsa, Petunjuk Praktis Penyusunan Balanced Scorecard; Menuju Organisasi yang Berfokus pada Strategi (kata sambutan), (Jakarta: PT Gramedia Pustaka Utama, 2004), Cet. III, h. xi. 
secara berkelanjutan dapat melakukan usahanya. Dalam ekonomi Islam, baik buruh ataupun pemodal adalah merupakan aktor pemain dari ekonomi. Oleh karena itu, keduanya harus berlaku adil. Mengenai butir kedua dari empat komponen di atas, yakni komponen bunga, Islam menolak/ melarangnya karena tidak sesuai dengan maqâshid al-syarîah. Sedangkan untuk ketiga komponen lainnya Islam memperbolehkan jika terpenuhi syarat-syarat dan batasanbatasannya.

Sebagian penulis ekonomi Islam berpendapat bahwa sistem distribusi yang harus diperhatikan adalah sistem distribusi yang tidak ada kaitannya dengan produksi, dimana pendistribusian pelbagai kebutuhan harus tetap dilakukan mengingat tidak semua manusia/masyarakat bisa ikut andil dalam sebuah produksi. Tetapi, ini juga bukan berarti Islam tidak menaruh perhatian pada kompensasi produksi. Distribusi dalam Islam didasarkan pada dua nilai kemanusiaan yang sangat mendasar dan penting, yakni nilai kebebasan dan nilai keadilan (distributive justice). ${ }^{6}$ Betapapun keterpautan antara manusia dalam pendapatan, sesungguhnya prinsip keadilan adalah tidak membiarkan kaum lemah menderita. Justru mereka harus dibantu dan dibimbing agar menjadi manusia kuat dan mandiri. Dan salah satu bentuknya adalah melalui jaminan sosial dengan sistem distribusi kekayaan.

Di Indonesia sesungguhnya sudah terbentuk lembaga-lembaga yang berorientasi pada hal tersebut di atas, hanya saja belum dikembangkan secara optimal serta belum ditata dan dikelola secara profesional. Dalam masalah zakat misalnya, persoalan kemungkinan terjadi karena para muzakkî masih melaksanakan kewajiban agama itu secara terpencar, disamping pula belum efektifnya lembaga zakat (BAZ/LAZ) menyangkut aspek-aspek pengumpulan administrasi, pendistribusian, monitoring serta evaluasi. ${ }^{7}$

Namun paling tidak telah dikeluarkan Peraturan Menteri Agama No.4/1968 tentang Pembentukan Badan Amil Zakat dan Peraturan Menteri Agama No. 5/1968 tentang Pembentukan Baitul Maal di tingkat Pusat, Propinsi, Kabupaten/ Kota, ditindaklanjuti kemudian dengan Keputusan Bersama Mendagri dan Menag No.29 dan 47/1991 tentang Pembinaan Badan Amil Zakat, Infak dan Shadaqah yang diikuti oleh instruksi Menag No. 5/1991 tentang Pembinaan Teknis BAZIS; dan Instruksi Mendagri No.7/1998 tentang Pembinaan Umum BAZIS. Bahkan kini,

${ }^{6}$ Yusuf Qaradhawi, Peran Nilai dan Moral dalam Perekonomian Islam (terjm), (Jakarta: Rabbani Press, 2001), h. 349.

${ }^{7}$ Djamal Doa, Membangun Ekonomi Umat Melalui Pengelolaan Zakat Harta, (Jakarta: Nuansa Madani, 2002), Cet. II, h. 47. 
perangkat hukum yang mengatur pengelolaan zakat tersebut telah disahkan oleh pemerintah, yakni Undang-Undang No.38/1999, yang mana UU ini sudah sampai pada tingkat penajaman penataan dan pengelolaan ZIS.

Di samping zakat, kita ketahui juga tentang sistem wakaf. Wakaf merupakan pranata sosial (philantropy) Islam yang bersifat volunteer (sukarela) dan mempunyai dampak ekonomi yang luas. Wakaf dalam ekonomi Islam bisa disebut juga dengan "shadaqah jâriyah" seseorang, yang pahalanya akan tetap mengalir setelah kematiannya.

Dalam sistem wakaf dijelaskan, bahwa harta yang dikeluarkan dari milik pribadi/individu untuk dialokasikan hasil dan manfaatnya pada salah satu sektor muamalat demi mengharap ridla Allah Swt., bisa memberikan kontribusi bagi kebutuhan masyarakat secara umum. Keadilan distribusi dari sistem wakaf ini adalah lebih pada pemanfaatan harta yang diwakafkan kepada masyarakat umum tanpa merusak/menghabiskan benda ('ain)-nya. Dengan demikian, hasilnya bisa dirasakan secara bersama-sama dan terus menerus. Eksistensi manajemen dan kinerja sistem dalam sebuah lembaga/organisasi merupakan suatu yang esensial, tanpa keduanya mustahil lembaga tersebut akan terus hidup dan berkembang. Fungsi manajemen bisa dikatakan sebagai fondasi bagi suatu lembaga. Oleh karenanya, adanya konsep manajemen yang mendevelop lembaga tersebut sangatlah dibutuhkan.

\section{Teori Distribusi Umum}

Persoalan distribusi dalam dunia ekonomi konvensional sangat erat kaitannya dengan pembahasan permasalahan produksi. Akhir dari sebuah produksi adalah konsekuensi, baik dalam bentuk nilai maupun uang, yang harus didistribusikan pada komponen-komponen produksi yang ikut andil dalam aktivitasnya, yaitu empat komponen yang terdiri atas: Pertama, upah bagi para pekerja. Kedua, bunga sebagai imbalan dari uang modal. Ketiga, ongkos untuk sewa bangunan/tanah. Keempat, laba bagi pengelola.

Perbedaan komposisi andil dalam produksi yang dimiliki oleh masingmasing individu di atas, berakibat berbeda pula terhadap pendapatan yang diperoleh oleh masing-masing individu tersebut. Secara teknis-mikro, jumlah pendapatan yang diperoleh pelbagai faktor produksi yang digunakan untuk menghasilkan suatu barang adalah sama dengan harga dari barang tersebut. Hal ini memberi penjelasan bahwa teori distribusi umum adalah merupakan segmen teori nilai yang berhubungan dengan determinasi harga-harga produksi ${ }^{8}$ yang

\footnotetext{
${ }^{8}$ Winardi, Pengantar Ilmu Ekonomi, (Bandung: Tarsita, 1975), Edisi V, h. 20.
} 
secara langsung dapat dikatakan, bahwa teori distribusi ini sangat terkait dengan teori pendapatan nasional, yang mana mekanisme tersebut memberi pengertian bahwa pendapatan nasional merupakan jumlah pendapatan faktor produksi yang ada dalam perekonomian.

Pada umumnya, sistem atau teori seperti di atas dianut oleh kaum industri kapitalis yang dalam ekonomi kapitalisnya, distribusi terfokus pada pasca produksi. Namun demikian, ekonomi kapitalis ini, khususnya aliran neoklasik, juga memberi gambaran tentang upaya mengurangi kemiskinan yang menjadi bagian dari pencapaian pemerataan dan kesejahteraan masyarakat melalui sistem trickle down effect (efek tetesan ke bawah), dimana peningkatan kekayaan kaum pengusaha-menjadi konglomerat-akan memberikan tetesan kekayaan mereka kepada masyarakat bawah dengan mendapatkan upah melalui usahanya sebagai buruh pabrik. ${ }^{9}$

Di sisi lain, menurut pandangan teori ekonomi publik, fungsi distribusi merupakan salah satu fungsi ekonomi negara yang memiliki keterkaitan erat dengan pemerataan kesejahteraan dan pendapatan masyarakat. Upaya pemerataan tersebut dilakukan melalui redistribusi kekayaan-kekayaan negara dari pelbagai pendapatan masyarakat, baik individu maupun perusahaan (yang biasa disebut pajak) yang kemudian digunakan untuk memenuhi kebutuhan negara dan pembangunan sarana prasarana umum demi kepentingan masyarakat bersama.

Pemerataan kesejahteraan secara proporsional ${ }^{10}$ juga mendorong pencapaian pertumbuhan ekonomi dengan optimal. Seperti ketentuan mengenai kebijakan retribusi tunggal (pajak proporsional) oleh pemerintah yang diseragamkan dianggap akan memicu optimalisasi. Selain itu, hal ini juga dilakukan menunjuk adanya kekhawatiran bila diberlakukan dengan tidak seragam akan menyebabkan migrasi penduduk yang berlebihan dari satu daerah ke daerah lain yang bisa memberikan penghasilan yang lebih besar. ${ }^{11}$ Untuk ukuran tingkat pemerataan pendapatan masyarakat, saat ini menggunakan rasio gini. Rasio gini berkisar antara 0 sampai dengan 1, dengan kriteria bahwa semakin tinggi gini rasio menunjukkan tingkat pendapatan yang semakin tidak merata. Angka 1 menunjukkan tidak merata sempurna, sedang 0 adalah merata sempurna.

\footnotetext{
${ }^{9}$ Hidayatullah Muttaqin, dalam http://www.alislam.or.id/comments/.

${ }^{10}$ Maksudnya, bahwa satu dearah dimungkinkan tidak sama tingkat kesejahteraannya dengan daerah lain karena akan sangat dipengaruhi oleh keberadaan dan kemampuan daerahnya tersebut masing-masing.

${ }^{11}$ Suyono P, dalam http://www.kimpraswil.go.id/bulletin/.
} 
Tingkat ketimpangan pendapatan penduduk digambarkan oleh porsi pendapatan dari kelompok pendapatan ini terhadap seluruh pendapatan penduduk, yang digolongkan sebagai berikut: (1) Memperoleh $<12 \%$, maka tingkat ketimpangan pendapatan dianggap tinggi; (2) Memperoleh 12-17\%, maka tingkat ketimpangan pendapatan dianggap sedang; (3) memperoleh $>17 \%$, maka tingkat ketimpangan pendapatan dianggap rendah.

Urutan distribusi pendapatan di atas menunjukan bahwa menurut kriteria Bank Dunia, ketimpangan pendapatan (pengeluaran) penduduk DKI Jakarta dalam periode tahun 1997-2001 dideteksi tergolong rendah (>17\%), yaitu 40\% penduduk lapisan paling bawah menerima pendapatan antara 19-23 persen dari total penduduk.

\section{Teori Distribusi Syariah}

Kahf dalam bukunya, The Islamic Economy, mengatakan bahwa Islam mempunyai dua prinsip utama dalam ekonominya, yaitu prinsip keseimbangan martabat dan persaudaraan dan pelarangan terhadap pemusatan (dawlah) kekayaan dan pendapatan. Ia juga mengatakan bahwa yang dibutuhkan oleh suatu negara (dan/atau masyarakat)_Islam-adalah menstruktur kebijakan ekonominya melalui: Pertama, memfungsikan pasar (market mecanism). Kedua, meminimalisasi gap distribusi (non-market mecanism). Ketiga, tidak mengingkari adanya perbedaan dalam kapabilitas dan intellegence diantara masing-masing individu dalam masyarakatnya. ${ }^{12}$

Dalam ekonomi Islam, segala kegiatan ekonomi harus senantiasa didasarkan pada prinsip-prinsip Alquran dan Hadis. Begitu juga dalam sistem distribusi. Q.s. al-Hasyr (59): 7 mengungkapkan, "Supaya harta itu jangan hanya beredar di kalangan orang-orang kaya saja diantara kamu".

Para pemikir ekonomi Islam juga memberikan gambaran tentang distribusi dalam Islam ini, seperti Sayyid Thâhir mengatakan bahwa terdapat beberapa perintah (injunction) distribusi dalam Islam, yaitu: Pertama, distribusi tidak selalu berhubungan dengan proses produksi tetapi lebih ditujukan untuk memperkuat proses redistribusi, seperti nafaqah wâjibah dan khums dari ghanîmah. Kedua, redistribusi wajib tahunan, seperti zakat. Ketiga, redistribusi antar-generasi, seperti hukum waris. Keempat, redistribusi yang didasarkan pada kepen-tingan publik (public interest), seperti permasalahan yang dipecahkan melalui

${ }^{12}$ Monzer Kahf, The Islamic Economy; Analytical Study of The Functioning of The Islamic Economic System, (Muslim Students Association of US and Canada, Plainfield.IN), h. 98. 
mashlahah mursalah dan istihsân. Kelima, redistribusi sukarela, seperti nafkah sukarela (infâq), hak tetangga, dan waqf. ${ }^{13}$

Begitu pula konsep distribusi menurut Shadr yang membaginya pada dua, yaitu distribusi pra produksi yang meliputi konsep kebutuhan dan tujuan sentral kerja, dan distribusi pasca produksi dimana distribusi merupakan kompensasi dari faktor-faktor produksi. Selain itu, ia juga menyebutkan tiga elemen perangkat dasar distribusi dalam Islam, yaitu: kerja, kebutuhan, dan properti. ${ }^{14}$

Islam juga sangat memperhatikan aspek perolehan pendapatan terutama melalui kegiatan ekonomi, seperti dalam hal sewa jasa atau upah. Komponen upah yang merupakan salah satu kompensasi terhadap faktor produksi, mendapat perhatian penting dalam distribusi pendapatan secara syariah.

Dalam Islam, konsep upah bermula dari bentuk kegiatan muamalah yang biasa disebut dengan ijârah, yang berarti menyewakan suatu barang untuk diambil manfaatnya yang di dalamnya terdapat ganti atas pemanfaatan tersebut. Ijârah dalam arti luas bermakna juga suatu akad yang berisi penukaran manfaat sesuatu dengan jalan memberikan imbalan dalam jumlah tertentu. ${ }^{15}$ Benham menyebutkan, "Upah dapat didefinisikan dengan sejumlah uang yang dibayarkan oleh yang memberi pekerjaan kepada seorang pekerja atas jasanya sesuai perjanjian". ${ }^{16}$

Adapun permasalahan upah ini sering dipicu oleh superioritas majikan dan kewajiban para pekerja ketimbang hak-hak dan kebutuhan pekerja itu sendiri. Karenanya sering terjadi pelanggaran tentang hak upah oleh para majikan yang akhirnya menimbulkan ketidakharmonisan antara pekerja dengan majikan (pemodal). Oleh karena itu, Islam memberikan jaminan terhadap hak-hak tersebut melalui ketetapan hukum-hukum kontrak kerja atau ijârah seperti di atas. Karena dalam Islam, upah bukanlah suatu konsekuensi melainkan suatu hak asasi.

Dalam hal lembaga-lembaga filantropi misalnya, aspek menjaga dan menyalurkan amanah adalah sebagai aspek kewajiban ilahiah yang diperintahkan oleh agama yang merupakan pengejawantahan dari nilai-nilai universal ajaran Islam. Yang mana nilai-nilai tersebut diantaranya: ketuhanan (tauhîd),

${ }^{13}$ IDB, Lesson in Islamic Economics Islamic, Reasech \& Institute Training, vol 2, 1 st edition, seminar proceeding no 41, 1998, h. 426.

${ }^{14}$ Chibli Mallat, Menyegarkan "Islam": Kajian Komprehensif Pertama atas Hidup Karya Muhammad Baqir Al-Shadr (terj.), (Bandung: Mizan Media Utama, 2001), Cet. I, h. 181 dan 206.

${ }^{15}$ Sayyid Sâbiq, Fiqih al-Sunnah, III, (Bayrût: Dâr al-Fikr, 1983), Jilid III, h. 198.

${ }^{16}$ Afzalurrahman, Doktrin Ekonomi Islam, h. 361. 
persaudaraan (brotherhood), kesetaraan (equal) dan keadilan (equity), kerja sama (cooperation) serta kerja dan produktivitas (productivity). Prinsip-prinsip ini sejatinya terkandung dalam segala kegiatan lembaga filantropi tersebut. ${ }^{17}$

\section{Distribusi Kekayaan Perspektif Ekonomi Islam}

Dalam Alquran dikatakan bahwa sumber dari segala hak dan kepemilikan yang sebenarnya adalah mutlak dari Allah Swt., karena Allah yang menciptakan alam raya ini dengan segala sesuatunya. Mutlak bahwa Allah pemilik segala sesuatu tersebut memberi pengertian akan arti kekuasaan Allah atas semua ini adalah tidak terbatas, baik jangkauan kekuasaannya maupun jangka waktunya. Hal ini seperti ditegaskan dalam Q.s. al-Mâidah [5]: 17 dan al-Baqarah [2]: 255, "Kepunyaan Allah-lah segala kerajaan langit dan bumi dan yang ada di dalam nya","Milik Allah segala yang ada di langit dan segala yang ada di bumi".

Namun di sisi lain dinyatakan bahwa meski segala kekayaan itu adalah milik Allah, namun kepemilikan pada manusia diakui secara de jure, karena Allah sendiri yang telah mengakaruniakan kekayaan dan Dia mengakui kepemilikan tersebut. Ini juga tercantum dalam Q.s. Yâsin (36): 71. Manusia dianggap sebagai istikhlâf (perwakilan) Allah ${ }^{18}$ dalam menjaga dan memanfaatkan segala miliki Allah tersebut. Dengan demikian, hak milik perseorangan (individu) dalam Islam adalah dibenarkan, tidak dilarang, baik berupa benda atau manfaat (utility) ataupun keduanya. Maka fakta ini pun dapat menjadi unsur legitimasi bagi konsep kepemilikan pribadi, yang berarti pula bahwa setiap manusia bisa menjadi pemilik sah dari suatu kekayaan sebagaimana disebutkan dalam Q.s. al-Nisâ (4): 32.

Hak milik tersebut juga tidak saja diakui, tetapi juga merupakan sesuatu yang harus dihormati dan dilindungi. Hak milik pribadi ini sudah menjadi bagian dari sistem Islam yang telah disyariatkan Allah, bahkan Rasul Saw. bersabda tentang ini, "Barang siapa terbunuh karena membela hartanya, ia mati syahid". (H.r. Muslim dalam kitab al-Misykah).

Mengenai hak milik pada manusia ini, pada hakikatnya memiliki dua kapasitas, yakni kapasitasnya sebagai pribadi yang bebas dan kapasitasnya sebagai anggota masyarakat. Hal inilah yang kemudian menunjukkan bahwa kepemilikan pada manusia itu (secara individu) dibatasi, sebagaimana tercantum

${ }^{17}$ Masudul Alam Choudhury, Contributions to Islamic Economic Theory; A Study in Social Economics, (NY: St Martin's Press), h. 8-9.

${ }^{18}$ Yusuf Qaradhawi, Peran Nilai dan Moral dalam Perekonomian Islam, (Jakarta: Rabbani Press, 2001), h. 39. 
dalam Q.s. al-Tawbah [9]:103, "Ambillah dari harta mereka sebagai sedekah, yang dengannya kamu mensucikan dan membersihkan mereka".

Di antara hal penting lain yang diungkapkan dalam ajaran Islam dalam hal pemilikan adalah adanya selain aturan pemilikan individu, yaitu penetapan aturan pemilikan umum (bersama) dalam suatu mayarakat, yang menyangkut kekayaan yang bersifat dharûrî (primer). Aturan ini menjadi penting mengingat keberadaan dan pemanfaatannya dibutuhkan sebagian besar manusia, sehingga pemilikannya pun bersifat bersama dan umum. Rasulullah Saw. menyebutkan diantara kekayaan yang dibutuhkan secara umum pada pokoknya ada tiga hal, yaitu: padang (rumput), air dan api. Dalam sebuah Hadis disebutkan, "Manusia berserikat dalam tiga hal, rumput, air dan api" (H.r. Abû Dâwud).

\section{Pemanfaatan Harta Kekayaan}

Dalam Islam hak pengelolaan ini merupakan konsekuensi dari hukum syarak, yang esensinya ia memiliki harta tersebut hanya untuk dimanfaatkan sesuai dengan ketentuan syara. Dimana cara dan usaha untuk memperoleh harta kekayaan dan penggunannya adalah amanat yang diberikan oleh Allah kepada manusia.

Walaupun keputusan untuk membelanjakan harta merupakan keputusan yang bersifat pribadi, tetapi dalam Alquran terdapat beberapa pedoman tentang pembelanjaan harta tersebut. ${ }^{19}$

Intinya, bahwa manusia Muslim diberi kebebasan dalam memanfaatkan kekayaannya, baik untuk disimpan atau diinvestasikan pada usaha (dalam hal ini dilakukan pada mekanisme pasar). Atau terus menyadari bahwa dalam harta kekayaan tersebut terkandung hal milik Allah yang harus diberikan kepada manusia lainnya yang sangat membutuhkan (dalam hal ini dilakukan pada mekanisme non-pasar). Dengan uraian sebagai berikut:

Pertama, melalui mekanisme pasar (distribusi syariah tentang akumulasi modal umat). Berbicara modal pasti akan terkait dengan laba atau keuntungan. Oleh karenanya, mekanisme pasar adalah mekanisme distribusi kekayaan yang lebih menitikberatkan pada sistem distribusi yang bersifat komersil/bisnis. Tidak saja dalam lingkup jual beli atau persewaan (untuk kepentingan diri), tetapi juga untuk diinvestasikan kepada masyarakat pengelola usaha yang kurang mampu sebagai modal usaha mereka dalam mengembangkan kapasitas produksinya. Mekanisme ini tentu saja memberikan multiplier effect pada kekayaan dua belah pihak, serta bagi pihak-pihak lain yang terkait di dalamnya.

\footnotetext{
${ }^{19}$ Q.s. al-Qashash [28]: 77 dan Q.s. al-Furqân [25]: 67.
} 
Kedua, melalui mekanisme non-pasar, antara lain melalui zakat dan wakaf. Kata zakat memiliki arti menumbuhkan, memurnikan atau memperbaiki yang mengandung makna pembersihan diri dan harta kekayan setelah melaksanakan kewajiban zakat. Dalam klasifikasi peribadatan Islam, kewajiban zakat sebagai salah satu rukun Islam, disebut sebagai ibadah mâliyah ijtimâ'iyyah (ibadah finansial dan sosial).

Terdapat beberapa unsur yang harus diperhatikan dalam pemanfaatan harta melalui zakat ini di antaranya: Pertama, unsur muzakkî, menurut Wahbah al-Zuhaylî yang disyaratkan menjadi seorang muzakkî adalah harus beragama Islam (Muslim), balig, berakal, dan merdeka (bukan hamba sahaya), memiliki harta yang mencapai nishâb dan hawl serta kepemilikan penuh (milk al-tâm) akan harta, dan terpenuhi kebutuhan pokok sehari-harinya dan keluarganya. Adapun Abdul Mannan menekankan enam prinsip sebagai karakteristik muzakki, yaitu: ${ }^{20}$ keyakinan, keadilan, produktifitas/sampai pada hawl, nalar, kemudahan, dan kemerdekaan.

Kedua, unsur mustahiq, Alquran memberikan perhatian khusus tentang kepada siapa zakat ini diberikan. Perhatian ini pada dasarnya adalah demi entasnya kemiskinan dan sejahteranya masyarakat. Ketentuan mustahiq ini adalah delapan golongan yang ditentukan Alquran dalam Q.s. al-Tawbah [9]: 60.

Ketiga, unsur mâl, yaitu mengenai jenis atau macam harta kekayaan apa saja yang harus dizakati. Dalam Q.s. al-Tawbah [9]: 60 dikatakan,"Ambillah zakat dari sebagian harta mereka, (di mana) dengan zakat itu kamu membersihkan dan mensucikan mereka". Ayat ini memberi pengertian, bahwa dalam Islam keharusan mengeluarkan atau membelanjakan harta melalui zakat adalah merupakan ibadah mahdhah yang bertujuan menyucikan mereka dari harta kekayaannya. Menurut Syafei' Antonio, zakat harta (mâl) bahkan merupakan salah satu bentuk konkret konsep trickle down effect (efek tetesan ke bawah) yang bersifat langsung dalam Islam.

Selanjutnya melalui mekanisme wakaf. Wakaf adalah sebentuk instrumen unik yang mendasarkan fungsinya pada unsur kebajikan (birr), kebaikan (ihsân), dan persaudaraan (ukhuwwah). Ciri utama wakaf yang sangat membedakan adalah ketika wakaf ditunaikan terjadi pergeseran kepemilikan pribadi menuju kepemilikan masyarakat Muslim yang diharapkan abadi, memberikan manfaat secara berkelanjutan. Melalui wakaf diharapkan akan terjadi proses distribusi

${ }^{20}$ M. Abdul Mannan, Teori dan Praktek Ekonomi Islam, (Yogyakarta: PT. Dana Bhakti Wakaf, 1997), h. 257-359. 
manfaat bagi masyarakat secara lebih luas, dari manfaat pribadi (private benefit) menuju manfaat masyarakat (social benefit). ${ }^{21}$

Pengertian wakaf menurut Ibn Qudâmah adalah, "Menahan asal dan mengalirkan hasilnya" ${ }^{22}$. Berdasarkan kutipan dari Hadis Nabi Saw. kepada Umar Ibn al-Khaththâb, yang mengisyaratkan kepadanya agar harta beliau diwakafkan, padahal ia tidak memiliki harta yang lebih berharga darinya. Dan tidak seorang pun sahabat yang memiliki kemampuan kecuali wakaf. ${ }^{23}$ Menurut al-Shan'ânî, wakaf adalah menahan harta yang mungkin dapat diambil manfaatnya tanpa menghabiskan atau merusakkan bendanya ('ayn) dan digunakan untuk kebaikan. $^{24}$

Sedangkan dalam bahasa hukum kontemporer, wakaf berarti pemberian, dilakukan atas kehendak ahli waris dengan satu niat memenuhi panggilan ketakwaan. Atau sebagai harta yang disumbangkan untuk pelbagai tujuan kemanusiaan, sekali dalam selamanya. Atau juga didefinisikan sebagai suatu tindakan penahanan dari penggunaan dan penyerahan aset tetap seseorang sebagai bentuk menifestasi kepatuhan terhadap agama, dimana orang lain dapat memanfaatkan atau menggunakan hasilnya untuk tujuan amal, sepanjang harta tersebut masih ada. ${ }^{25}$ Bahkan Komisi Fatwa Majelis Ulama Indonesia dalam putusan fatwanya tentang wakaf tunai memberikan pengertian bahwa wakaf adalah perbuatan hukum seseorang atau kelompok orang atau badan hukum yang memisahkan sebagian dari benda miliknya guna kepentingan ibadat atau keperluan umum lainnya sesuai dengan ajaran Islam" dan "Benda wakaf adalah segala benda, baik bergerak atau tidak bergerak, yang memiliki daya tahan yang tidak hanya sekali pakai dan bernilai menurut ajaran Islam. ${ }^{26}$

Dengan demikian secara aplikatif, dalam hukum Islam, wakaf berarti menyerahkan suatu hak milik yang tahan lama (zatnya) kepada seseorang atau nadzir (penjaga wakaf) baik berupa perorangan maupun lembaga, dengan ketentuan bahwa hasilnya digunakan sesuai dengan syariat Islam. Harta yang

21 Abdul Aziz Setiawan, dalam http://www.hidayatullah.com/index.php?option=com_ content\&task $=$ view\&id $=1505 \&$ Itemid $=0$

${ }^{22}$ M. Abid Abdullah al-Kabisi, Hukum Wakaf, (Jakarta: Ilman dan Dompet Dhu'afa Republika, 2004), Cet. I, h. 61.

${ }^{23}$ Yusuf Qaradhawi, Peran Nilai dan Moral dalam Perekonomian Islam, h. 428.

${ }^{24}$ Muhammmad bin Ismâ'îl al-Shan'ânî, Subul al-Salâm, Juz III; Muhammad 'Alî al-Shâbûnî, tanpa tahun, h. 114.

${ }^{25}$ M.A. Mannan, Sertifikat Wakaf Tunai; Sebuah Inovasi Instrumen Keuangan Islam, (Jakarta: Ciber, PkttI-UI, terjmh, 2001), h. 29.

${ }^{26}$ Kompilasi Hukum Islam di Indonesia, Buku II, Bab I, Pasal 215, (1) dan (4). 
telah diwakafkan keluar dari hak milik yang mewakafkan (wâqif), dan bukan pula hak milik nadzir/lembaga pengelola wakaf tapi menjadi hak milik Allah yang harus dimanfaatkan untuk kesejahteraan masyarakat. ${ }^{27}$

Menurut Imam Dahlawi, wakaf memiliki keistimewaan yang tidak dimiliki oleh jenis sedekah yang lainnya. Dimana infak yang diberikan, berbentuk paten dan bertahan lama, sehingga dapat dimanfaatkan secara terus-menerus. Dengan demikian, sasarannya bukan sekadar orang fakir dan miskin, namun juga untuk kepentingan publik dan masyarakat luas.

Saat ini peran ekonomi Islam, tidak saja langsung bersentuhan dengan pergulatan konsep dan pemahaman ekonomi konvensioanl, namun juga membuka diri dengan sistem-sistem aplikatif terbaru yang memerlukan pengkajian, pendalaman ulang terhadap fikih klasik agar dapat dimanfaatkan saat ini. Seperti dalam hal wakaf adalah dengan adanya wakaf uang.

Sertifikat Wakaf Tunai misalnya, merupakan produk baru yang dikembangkan saat ini yang juga merupakan bagian tidak terpisahkan dari sistem ekonomi Islam yang integral dan merupakan inovasi tunggal milik konsep Islam. Sesuai dengan tujuan wakaf, maka Sertifikat Wakaf Tunai adalah sebagai salah satu bentuk tanggung jawab sosial dari yang mampu kepada yang berhak menerimanya, baik untuk sektor pendidikan sosial maupun ekonomi. Menurut Mannan, sesungguhnya penggunaan wakaf tunai telah lama dikenal di dalam pemerintahan Islam. ${ }^{28}$ Dia menyebutkan bahwa penggunaan wakaf uang sudah ada semenjak zaman pemerintahan Utsmaniyah dan kekhalifahan Ottoman.

\section{Deskripsi Sistem Distribusi Syariah di Indonesia: Analisis Kinerja Badan/ Lembaga Zakat dan Wakaf}

Pertama, lembaga zakat. Secara sosial, praktik-praktik zakat sudah terlaksana semenjak agama Islam itu ada di Indonesia. Baik itu dilakukan secara mandiri -langsung kepada mustahik atau melalui para ulama, kyai, atau ustazmaupun secara kolektif yang bersifat sporadik (kelompok-kelompok kecil dalam masyarakat), juga bersifat tradisional-pasif dan hanya temporer (musiman).

Misi zakat sendiri sesungguhnya selaras dengan Undang-Undang Dasar 1945 pada pasal 34 yang menyatakan bahwa, "Fakir miskin dan anak-anak terlantar dipelihara oleh negara". Jiwa zakat sudah melekat dalam kehidupan sosial masyarakat Indonesia. Negara merupakan "'âmilîn" yang tepat dalam

\footnotetext{
${ }^{27}$ Dian Masyita Juhelmi, dalam http//www.tazkiaonline.com/.

${ }^{28}$ M.A. Mannan, Sertifikat Wakaf Tunai, h. 95.
} 
menjalankan amanat tersebut. Karena berbicara zakat, esensinya adalah bicara tentang how to manage the zakah's fund.

Pada tahun 1990, DPR menyetujui Rancangan UU tentang zakat yang kemudian tersahkan menjadi UU No.38 Tahun 1999 tentang Pengelolaan Zakat. Pembentukan Lembaga Pengelola Zakat (LAZ/BAZ) ini juga, secara paralel berpengaruh kuat atas optimalisasi zakat yang nyata-nyata membutuhkan sistem pengelolaan yang profesional dan legitimate. Bahkan, ayat pertama pasal 7 UU No.38/1999, menentukan bahwa Lembaga Amil Zakat dikukuhkan, dibina, dan dilindungi oleh pemerintah.

Sehingga instrumen zakat ini bisa dijadikan alat kebijakan ekonomi negara sebagai sumber pendanaan baru bagi pemerintah. Diantaranya perkiraan potensi zakat yang dilakukan oleh Nasution ${ }^{29}$ dengan menggunakan data GDP Indonesia dan dengan asumsi bahwa penguasaan asset umat muslim sebesar 20\% dari total GDP dan besaran zakat sebesar 2,5\% maka potensi zakat adalah sebesar 7,5 s.d 8,7 trilyun rupiah atau sekitar 0,4 s.d $1,85 \%$ dari total PDB nasional (berdasarkan harga berlaku tahun 2005). Jika dibanding dengan estimasi dan perhitungan potensi zakat di beberapa negara muslim, jumlah ini masih jauh lebih rendah. Namun hal yang menggembirakannya adalah jumlah ini terus mengalami peningkatan dari tahun ke tahun.

Kedua, lembaga wakaf. Kementerian Agama RI telah membuat satu divisi, khusus tentang Pengembangan Wakaf untuk masyarakat muslim Indonesia, yang disebut dengan Badan Wakaf Indonesia (BWI). Keberadaan BWI adalah melaksanakan pembinaan yang intensif bagi para pengelola wakaf di seluruh Indonesia. Sekaligus menjadi lembaga pengontrol bagi para pengelola wakaf yang ada di Indonesia.

Sistem perwakafan di Indonesia sudah berjalan dan berkembang, terbukti dengan adanya pelbagai produk wakaf, yang tidak hanya bersifat sosial produktif, tetapi juga sudah menyentuh manajemen pembiayaan global, seperti dengan adanya sistem wakaf uang. Selain itu, wakaf uang ini juga telah mendapatkan putusan wakaf dari Majelis Ulama Indonesia tentang wakaf uang. ${ }^{30}$

\section{Sistem Distribusi Syariah pada Lembaga Zakat dan Wakaf di Indonesia}

Membentuk serta melembagakan aspek filantropi dalam Islam seperti zakat dan wakaf ini merupakan transformasi makna wajib dari perintah Allah

${ }^{29}$ Mustafa E. Nasution, Yusuf Wibisono, Zakat Sebagai Instrumen Pengentasan Kemiskinan”, Proceeding Muktamar IAEI, Medan, 2005.

${ }^{30}$ http://www.mui.or.id/fat_wakafuang.htm 
dalam Alquran yang mengandung makna fardh kifâyah, yang menjadi suatu kewajiban bagi kaum muslimin untuk mengelola secara sistematis segala harta yang wajib dikeluarkan tersebut. Berbicara sistem, berarti tidak terlepas dari aspek perilaku penataan, semakin baik seseorang menata diri, berarti semakin baik ia melakukan proses manajemen. Tidak itu saja, perencanaan strategis, SWOT dan hadirnya orang-orang yang cakap di bidangnya adalah tuntutan progresif untuk pengembangan lembaga-lembaga tersebut. ${ }^{31}$

\section{Faktor Kekuatan (Strengths)}

Pertama, penggunaan sumber daya insani yang profesional. Untuk menggerakkan lembaga filantropi ini menjadi suatu lembaga yang profesional, maka perekrutan sumber daya manusianya harus profesional. Banyaknya kaum elit intelektual yang terjun langsung dalam pengelolaan lembaga filantropi menunjuk hal tersebut.

Kedua, populasi penduduk Indonesia muslim yang mampu (kaya). Faktor ini jelas menjadi suatu kekuatan terbentuknya lembaga-lembaga yang bergerak di bidang filantropi. Hal ini juga merupakan alasan kuat supaya pemerintah terus mendukung upaya pemerataan kesejahteraan ini dengan memberikan kemudahan dalam aspek hukum atau perundang-undangannya.

Ketiga, legalitas lembaga. Dalam hal ini pemerintah membentuk 2 (dua) lembaga resmi yang khusus mengelola zakat, yakni BAZNAS dan BAZ. Demikian pula halnya dengan wakaf, ketentuan tentang wakaf adat orang Indonesia ini banyak dipengaruhi oleh ajaran Islam, yaitu Peraturan Pemerintah No. 28 Tahun 1977.

\section{Faktor Kelemahan (Weakness)}

Pertama, kurangnya sosialisasi. Dengan sikap yang pasif maupun reaktif tadi, hal inilah yang menyebabkan kurangnya sosialisasi lembaga mengenai aspek filantropi kepada masyarakat muslim yang mampu. Meski penduduk Indonesia mayoritas beragama Islam, namun pengetahuan akan aspek filantropi ini masih sangat minim.

Kedua, pengendalian mutu manajemen. Profesionalisme sebagai salah satu pengendali mutu manajemen, harus dibangun dari sebuah kesadaran, kegigihan, dedikasi dan komitmen, keberanian dan kepatuhan serta cita-cita.

${ }^{31}$ Eri Sudewo, Manajemen Zakat; Tinggalkan 15 Tradisi, Terapkan 4 Prinsip Dasar, (Ciputat, IMZ, 2004), Cet. I, h.xxxviii. 
Ketiga, minimnya pembelajaran dan pelatihan bagi pengelola. Demi tetap eksisnya lembaga-lembaga filantropi ini, maka aspek pembelajaran dan pelatihan bagi para pengelola lembaga tersebut menjadi hal yang sangat penting.

\section{Peluang (Opportunity)}

Pertama, peningkatan kesadaran umat Muslim terhadap aspek filantropi. Faktor ini memang menjadi faktor andalan berkembangnya aspek filantropi Islam di Indonesia. Hal ini juga yang mampu mendorong terbukanya pengukuhan peraturan dan undang-undang yang mendukung terbentuknya lembagalembaga yang bergerak dibidang filantropi tersebut.

Kedua, perkembangan teknologi ekonomi dan informasi. Perkembangan teknologi informasi modern saat ini memberikan peluang yang besar pada lembaga-lembaga tersebut, baik sebagai sarana maupun prasarana untuk menjadikan lembaganya sebuah organisasi dengan mutu manajemen yang profesional dan bertanggung jawab.

Ketiga, pengembangan pelbagai program layanan dan perluasan jaringan. Banyaknya program-program produktif yang dibuat oleh lembaga tersebut dan jaringannya akan mampu mendorong para donatur untuk mengeluarkan hartanya dan melihat sejauhmana dana-dana tersebut termanfaatkan.

\section{Tantangan/Ancaman (Threats)}

Pertama, peningkatan angka kemiskinan. Realitas masyarakat yang tadinya mampu membeli makanan yang mempunyai nilai gizi minimal, saat ini mendapatkan makanan sederhana saja sudah untung. Ini bukan berarti yang kaya menjadi miskin, tetapi masyarakat yang sebelumnya punya daya beli menjadi tidak berdaya beli.

Kedua, tingkat keluhan mustahik terhadap program layanan. Tidak sedikit memang para mustahik yang senantiasa mengajukan permohonan bantuan kepada lembaga filantropi, karena mereka berpendapat bahwa mereka laik untuk diberi. Hanya saja mereka kemudian menjadi enggan disebabkan lembaga terkadang sangat selektif.

Ketiga, berkurangnya tingkat kepercayaan donatur pada lembaga. Penyebab utama yang mengganggu faktor ini adalah kapabilitas lembaga dalam menjalankan aktivitasnya, seperti kurang kreatif, tidak proaktif, tidak transparan, tidak fleksibel, birokrasi yang terlalu berbelit-belit, atau yang paling ekstrim adalah tidak amanah. 


\section{Rencana Aksi}

Pertama, regulasi pembentukkan lembaga. Agar lembaga-lembaga zakat dan wakaf mampu menunjukkan kapabilitasnya sebagai sebuah sistem pendistribusian ekonomi (dalam hal harta kekayaan) serta sebagai lembaga keuangan nirlaba (non-profit), menjadi bagian tak terpisahkan pada pembangunan perekonomian bangsa, dalam rangka meningkatkan kesejahteraan ekonomi umat umumnya dan masyarakat miskin (tidak mampu) pada khususnya.

Dalam hal ini, pemerintah pusat harus dengan sungguh-sungguh menyediakan perangkat hukum yang jelas dan tepat bagi terselenggaranya pembangunan dan pengembangan lembaga-lembaga zakat dan wakaf di Indonesia. Adapun Pemerintah Daerah tingkat I dan II adalah perpanjangtanganan pemerintah pusat dalam merealisasikan perangkat hukum yang dikeluarkan. Dalam hal ini Pemda Tingkat I dan II diharapkan mampu menfasilitasi lembaga-lembaga zakat dan wakaf yang dikelola langsung dari masyarakat, agar dapat memiliki perizinan dengan cepat dan benar seperti yang ditentukan pemerintah pusat.

Kedua, mobilisasi sumber-sumber dana. Berdasarkan identifikasi faktorfaktor yang bisa memberi kekuatan terhadap berdiri dan berkembangnya lembaga-lembaga zakat dan wakaf, yakni populasi penduduk muslim dan mampu di Indonesia, maka lembaga harus melakukan penggalian dana dengan menawarkan program kerja dan program layanan yang signifikan, sehingga dana-dana yang diberikan dapat diserap dan disalurkan dengan baik dan benar. Selain itu peta progresifitas dana yang masuk dapat terlihat melalui pelaporan yang dibuat oleh manajemen lembaga.

Ketiga, sosialisasi dan advokasi. Bahwa masih banyak masyarakat Muslim Indonesia yang kaya tidak begitu memahami makna dari zakat dan wakaf atau aspek filantropis lainnya, adalah sesuatu yang harus disadari. Oleh karenanya, sistem sosialisasi dan advokasi mengenai pemaknaan zakat dan wakaf adalah bagian terpenting dari program. Tidak saja secara personal, tetapi juga pada kelompok masyarakat dan lembaga-lembaga/instansi. Pendekatan yang digunakan dapat beragam, baik melalui seminar, ceramah, personal approach, maupun secara didaktis-metodis.

Keempat, peningkatan mutu manajemen dan pembelajaran karyawan. Setidaknya terdapat dua sasaran utama dalam hal peningkatan ini yaitu meningkatkan kualitas lembaga dengan pelbagai fasilitas dan meningkatkan profesionalisme âmilîn. 


\section{Penutup}

Dalam pandangan ekonomi Islam, sistem distribusi merupakan bagian kegiatan ekonomi yang mempunyai pengaruh kuat terhadap pemerataan kesejahteraan masyarakat. Sistem distribusi menurut Islam adalah aturan yang tidak dapat dipisahkan dari ketentuan maqâshid syarîah, yang di dalamnya terdapat aspek distribusi kekayaan yang bersifat wajib seperti sistem zakat dan wakaf.

Keberadaan lembaga zakat dan wakaf di Indonesia terhitung cukup lama, namun pengelolaan lembaga-lembaga tersebut sangat terbatas dan sporadis. Pengelolaannya pun masih tradisional dan musiman.

Kemudian hadir "kebaikan" dengan adanya legalitas kelembagaan ini. Sehingga, pengelolaan lembaga zakat dan wakaf dapat diorganisir dengan menggunakan sistem manajemen yang baik. Selain didukung oleh perangkat hukum atau undang-undang, aspek manajerial sangat menentukan kualitas dan kapabilitas lembaga tersebut. []

\section{Pustaka Acuan}

Al-Kabisi M. Abid Abdullah, Hukum Wakaf, Jakarta: Ilman dan Dompet Dhu'afa Republika, 2004.

Choudhury, Masudul Alam, Contributions to Islamic Economic Theory; A Study in Social Economics, NY: St Martin's Press.

Doa, Djamal, Membangun Ekonomi Umat Melalui Pengelolaan Zakat Harta, Jakarta: Nuansa Madani, 2002.

Eri Sudewo, Manajemen Zakat; Tinggalkan 15 Tradisi, Terapkan 4 Prinsip Dasar, Ciputat: IMZ, 2004.

Kahf, Monzer, The Islamic Economy; Analytical Study of The Functioning of The Islamic Economic System, Muslim Students Association of US and Canada, Plainfield.IN.

Mallat, Chibli, Menyegarkan "Islam"; Kajian Komprehensif Pertama atas Hidup Karya Muhammad Baqir Al-Shadr (terjm), Bandung: Mizan Media Utama, 2001.

Mannan, M. Abdul, Teori dan Praktek Ekonomi Islam, Yogyakarta: PT. Dana Bhakti Wakaf, 1997.

-----------, Sertifikat Wakaf Tunai; Sebuah Inovasi Instrumen Keuangan Islam, Jakarta: Ciber, PkttI-UI, terjmh, 2001.

Mubyarto, Islam dan Kemiskinan, Penerbit: Pustaka, Bandung, 1988.

Nasution, Mustafa E. dan Yusuf Wibisono, Zakat sebagai Instrumen Pengentasan Kemiskinan", Proceeding Muktamar IAEI, Medan, 2005. 
Qaradhawi, Yusuf, Peran Nilai dan Moral dalam Perekonomian Islam (terj.), Jakarta: Rabbani Press, 2001.

Shan'ânî, Muhammmad Ibn Ismâ'il, Subul al-Salâm, Juz 3.

Winardi, Pengantar Ilmu Ekonomi, Bandung: Tarsita, 1975. 